\title{
PENGEMBANGAN HUKUM ISLAM PERSPEKTIF FILSAFAT
}

\author{
Mohammad Romli \\ Institut Pesantren KH. Abdul Chalim Mojokerto \\ Email; romlimuhammad31@gmail.com
}

\begin{abstract}
In the concept of Islamic law, the discussion of Islamic law, the discussion of law covers matters relating to the term law, judge, mahkum fih, and mahkum alaih. The first thing that needs to be explained is not the law, but the judge, that is the party who sets the law or the law maker and determines the merits of an act. In the principles of Islamic law, the Judge is Allah $S W T$. The reason that the first judge must be discussed is because without a judge there is no Islamic law.
\end{abstract}

Keywords: Islamic Law, Philosophy

\begin{abstract}
Abstrak
Dalam konsep hukum Islam, pembahasan hukum islam, pembahasan hukum meliputi hal-hal yang berhubungan dengan istilah hukum, hakim, mahkum fih, dan mahkum alaih. Yang pertama perlu diuraikan bukan hukum, melainkan hakim, yaitu pihak yang menetapkan hukum atau pembuat hukum dan menetapkan baik buruknya suatu perbuatan. Dalam prinsip hukum islam, Hakim adalah Allah $S W T$. Alasan bahwa hakim yang pertama harus di bahas karena tanpa hakim maka hukum islam tidak ada.
\end{abstract}

Kata kunci: Hukum Islam, Filsafat

\section{PENDAHULUAN}

Dalam konsep hukum Islam, pembahasan hukum meliputi hal-hal yang berhubungan dengan istilah hukum, hakim, mahkum fih dan mahkum 'alaih. Yang pertama perlukan adalah hakim, yaitu pihak yang menetapkan hukum atau pembuat hukum dan menetapkan baik-buruknya sebuah perbuatan. Dalam prinsip hukum Islam, hakim adalah Allah Swt. Guna membawa dan menyampaikan hukum atau syariat kepada manusia, Hakim, yaitu Allah menciptakan utusan-utusan yang disebut dengan Rasulullah. Sebelum Allah mengut us para Rasul, tidak ada syari'at yang berlaku.

Hukum tidak tercipta dan hadir dengan sendirinya, melainkan melalui proses tertentu yang berhubungan dengan kodrat alam dan kemanusiaan. Hukum yang merupakan system alam disebut dengan nature of law (hukum alam). Hukum alam berjalan dengan fitrahnya. Fitrah yang paling mendasar dalam hukum alam adalah perubahan dan penggantian. Tak ada sesuatu yang tetap didalamnya, segala sesuatu akan memudar, dan setelah itu mati. 
Bagi umat manusia, Allah adalah Subjek hukum, sebagai Pembuat hukum. Jika Allah dikatakan Pelaku hukum yang diciptakannya sendiri, Dia adalah Dzat yang memiliki hakikat Dzatnya sendiri. Dzat yang memiliki sifat dan Af'al (perilaku). Apabila manusia menyadari dan meyakini dengan semua fitrah alamiah ini, bahwa tiada hukum yang paling benar, kecuali hukum-hukum Allah, perjalanan manusia akan senantiasa waspada dengan setiap perubahan dalam kehidupan yang fana ini. ${ }^{1}$

Dengan pemahaman diatas, pengembangan hukum islam di lihat dari kaca mata filsafat, hukum Islam yang pertama dan sumber hukum Islam adalah pembuat hukum Islam itu sendiri.sumber hukum islam terdiri dari tiga, antara lain: Pembahasan pertama yang berkaitan dengan sumber hukum Islam adalah membicarakan tentang Allah sebagai salah satu kajian filsafat, tidak terkecuali filsafat hukum islam.

\section{AL-HAKIM}

Dzat yang menciptakan hukum sebagai peraturan hidup manusia adalah dzat yang mutlak, yang keberadaannya tidak di tentukan atau bergantung pada yang lain. Dengan demikian dzat yang menciptakan kebenaran dan menetapkan yang "benar dengan sendirinya" adalah Al Hakim. Kebenaran yang tidak membutuhkan legalitas dari kebenaran buatan makhluk-Nya. Hakim atau Allah yang mengangkat manusia menjadi seorang nabi dan rasul yang menerima risalah dan firman firmannya-Nya yang tertuang dalam kitab suci yang orisinalitasnya di jaga dan dipelihara secara langsung oleh pembuat hukum itu sendiri. ${ }^{2}$

Selain Al-Hakim atau Asy-Syari', aspek lain yang menjadi bagian penting dalam hukum islam adalah hukum islam itu sendiri yang di dalamnya terdapat berbagai tuntunan dan tuntutan serta ketetapan yang berhubungan dengan perbuatan manusia yang sufdah baligh dan berakal.

Kemudian, dibahas tentang Mahkum Fih, yakni perbuatan yang dihukumkan (perbuatan umum). Perbuatan yang di hukumkan ada lima, sebagai akibat dari bermacam-macam isi dan maksud yang terkandung dalam firman Allah dan sabda

\footnotetext{
1 Masdar F. Mas'udi, "Meletakkan Kembali Maslahat Sebagai Acuan Syari'ah" Jurnal Ilmu dan Kebudayaan Ulumul Qur'an No.3, Vol. VI Th. 1995.

${ }^{2}$ Izzuddin ibn Abd al-Salam, Qawaid al-Ahkam fi Masalih al-Anam (Kairo: al-Istiqamat, t.t)
} 
Rasulullah SAW. yang keduanya dinyatakan oleh ulama ahli ushul sebagai dasar hukum. Perbuatan hukum disebut juga dengan at-taklif.

Perbuatan yang dihukumkan berhubungan dengan mukallaf atau Mahkum Alaih, yaitu subjek hukum atau pelaku yang perbuatannya menjadi tempat berlakunya hukum Allah. Dengan demikian, aspek hukum islam itu terdiri dari Hukum, Hakim, Mahkum Alaih. Pautan utama dari Hakim atau Syari', hukum atau Asy-Syara' adalah Allah SWT. Sebagai pembuat hukum, Al Quran sebagai dalil-dalil hukum, Rasululah SAW. sebagai Al-mubayyin, yaitu yang menjelaskan dalil-dalil dalam Al Quran, dan di lanjuntukan oleh para ahli waris nabi, yakni para ulama, cendekiawan muslim, ulul albab, wali-wali Allah, dan orang-orang yang tergolong al-mustadhil, yang memiliki kemampuan atau mumpuni dalam melakukan istinbath hukum dan istidhal. ${ }^{3}$

\section{WAHYU}

Pembahasan yang kedua adalah wahyu sebagai sumber islam yang kedua setelah al hakim. Yang terpenting dari segala yang penting setelah meyakini bahwa sumber hukum islam adalah Al-Hakim atau Asy-Syari' yang menciptakan atau menurunkan hukum syara', adalah meyakini bahwa yang diciptakan dan diturunkan-Nya merupakan wahyu yang terbebas dari campur tangan makhluk-Nya. Wahyu yang di jaga dan di pelihara secara langsung oleh Al-Hakim.

Mengenai pengertian wahyu, ada perbedaan pendapat di kalangan ahli tafsir. Menurut bahasa, wahyu itu artinya bisikan, atau membisikkan ke dalam hati, mengilhamkan atau isyarat yang cepat dan sangat rahasia. Menurut Mana' Al-Qathan (1973 :32), yang di maksud dengan wahyu adalah al-isyarah asy-syari'ah, yakni pesanpesan Allah yang di sampaikan dengan gemerincing lonceng, suara lebah, lewat mimpi, dan melalui Malaikat Jibril yang menyerupakan seorang laki-laki. Isi dari semua wahyu hanya Rasulullah SAW. yang mengetahuinya atas dasar pengetahuan yang diterima secara langsung dari Allah SWT. Oleh karena itulah, makna wahyu adalah bisikan yang tersembunyi, rahasia, atau bishautin mujaradin. ${ }^{4}$

\footnotetext{
3 Al-Gazali, al-Mustasfa min Ilm al-Usul (Kairo: al-Amiriyah, 1412).

${ }^{4}$ Muhammad Sa'id Ramdan al-Buti, Dawabit al-Maslahah fi as-Syariah al-Islamiyah, (Beirut: Mu'assasah ar-Risalah,1977).
} 
Pemahaman tentang wahyu didasarkan pada pengertian pengertian tersebut adalah:

1. Allah SWT. Memerintahkan malaikat turun membawa titah Allah tentang Amr dan Nahyu-Nya untuk manusia.

2. Malaikat adalah para pesuruh Allah yang bertugas menyampaikan semua perintah Allah untuk manusia.

3. Allah SWT. Membisikkan suatu makna ke dalam hati orang yang dikehendakiNya.

4. Allah SWT. Memperdengarkan kalam-Nya kepada siapa saja yang dikehendakiNya tanpa perantara dan tanpa penampakan.

5. Allah SWT. Memerintahkan Rahul Qudus dan Ruhul Amin, yakni Jibril, agar membisikkan perintah-Nya kepada jiwa Nabi. ${ }^{5}$

Menurut Hasbi Ash Shidieqie, cara ketiga, keempat, dan kelima dijelaskan oleh surat Ash Shu'ara ayat 52 yang artinya" Dan kami wahyukan (perintahkan) kepada Musa: "Pergilah di malam hari dengan membawa hamba-hamba-Ku(Bani Israil), Karena Sesungguhnya kamu sekalian akan disusuli".

Ayat tersebut menjelaskan bahwa makna wahyu adalah membisikkan ke dalam sukma. Dar ayat itu dapat di pahami bahwa cara-cara Allah SWT. Menyampaikan kitabkitab-Nya kepada Raasul adalah dengan tiga macam, yaitu:

1. Menurunkan wahyu

2. Memperdengarkan suara dari belakang hijab ( menampakkan pelakunya, rahasia).

3. Mengutus rasul dan malaikat atau mengirim seorang pesuruh untuk menyampaikan wahyu. ${ }^{6}$

Di samping wahyu Al Qur'an menjadi sumber hukum setelah al hakim itu

Sendiri, maka setelah itu yang menjadi sumber hukum adalah sunah nabi.Menurut bahasa As-Sunnah artinya jalan atau tuntunan, baik yang terpuji maupun yang tercela.

Secara terminologis, menurut ahli hadist, As-Sunnah adalah segala sesuatu yang bersumber dari Nabi Muhammad SAW. dalam bentuk ucapan, perbuatan, dan taqrir

\footnotetext{
${ }^{5}$ Nur A. Fadhil Lubis, Hukum Islam dalam Kerangka Teori Fikih dan Tata Hukum Indonesia (Medan :Pustaka Widyasarana,1995)

${ }^{6}$ Hasbi Ash Shidieqie (1990: 13),
} 
(persetujuan Rasul karena perbuatan sahabat yang tidak dilarang dengan cara membiarkannya ketika perbuatan sahabat yang tidak dilarang dengan cara membiarkannya ketika perbuatan tersebut dilakukan), perangai, sopan sant un dan sepak terjang perjuangannya, baik sebelum atau sesudah beliau di angkat menjadi rasul. ${ }^{7}$

Bagi umat islam yang beriman dan yakin pada kebenaran Al-Quran, ia tidak akan keluar dari hukum-hukum yang telah di tetapkan oleh Allah dan Rasul-Nya. Sumber utama umat keteladanan umat islam adalah Al-Quran dan Al-Hadis, bukan sunnah, yang benar adalah "sunnah harus bersumber kepada Al-Quran dan Al-Hadis". Al Quran menyajikan ayat-ayat yang berkaitan dengan masalah aqidah, ibadah, dan masalah muamalah. Apabila dalam Al Quran tidak ditemukan ayat-ayat yang menujuk pada dalildalil perbuatan tertentu, dalil yang diperlukan diambil dari Al-Hadis, sehingga Al Quaran sering dikatakan sebagai kalamullah yang sifatnya global, sedangkan hadis mengkhususkan, menafsirkan menjelaskan lebih rinci, dan menguatkannya (taukid).

Kedudukan hadis mendapat urutan kedua setelah Al Quran. Hadis adalah segala sesuatu yang disndarkan pada Nabi SAW. berupa perkataan, perbuatan, dan taqrirnya. Secara kualitas dari sudut sanad, rawi dan matannya, hadis dibagi tiga, yakni hadis sahih, yakni hadis yang diriwayatkan oleh perawi yang adil, dhabit dan tsiqah, sanadnya bersambung, dan matannya tidak ada illat atau syadz, sedangkan dari kuantitas rawinya, terdapat hadis mutawatir yang diriwatkan oleh rawi yang jumlahnya banyak dan tidak bersepakat untuk berdusta. Hadis ahad yang terbagi atas hadis masyhur, aziz, dan gharib, yang jumlah rawinya tidak sama dengan hadis mutawatir. Antara tiga, dua dan bisa saja seorang rawi. ${ }^{8}$

\section{AKAL}

Akal manusia tidak akan mampu mengetahui hakikat sesuatu secara sempurna terlebih bila hakikat itu meliputi berbagai permasalahan.

Fungsi akal manusia yang paling besar adalah untuk mengetahui hakikat kebenaran. Apa kebenaran sejati itu? Sekali lagi bagi orang yang fitrah masih suci akan

\footnotetext{
${ }^{7}$ Theo Huijbers, Filsafat Hukum dalam lintasan sejarah, cet VIII, Yogyakarta: kanisius, 1995

${ }^{8}$ Nur A. Fadhil Lubis, Hukum Islam dalam Kerangka Teori Fikih dan Tata Hukum Indonesia (Medan :Pustaka Widyasarana,1995), 34-35.
} 
mengakui bahwa hanya dengan akal seorang manusia tidak akan mencapai kebenaran sejati. Ia akan mengakui untuk mengetahui kebenaran harus melalui bimbingan Pencipta yaitu Allah.

Namun tidak demikian dengan orang-orang yang terlalu "percaya diri" dengan kemampuan akalnya. orang-orang yang merupakan penerus dari paham Mu'tazilah ini merasa tidak butuh dengan bimbingan Allah untuk mengetahui kebenaran. Tidak cukup sampai di situ bahkan dengan lancang mereka "mengobrak-abrik" syariat Allah yang menurut akal mereka bukan merupakan kebenaran. ${ }^{9}$

Di Indonesia gerakan ini sudah berlangsung cukup lama antara lain dipelopori oleh Nurcholis Madjid Munawir Syadzali Ahmad Wahib Harun Nasution dan lain-lain. Kini para pengusung madzhab ini bergabung dalam sebuah "sindikat" bernama Jaringan Islam Liberal yang dikomandani oleh Ulil Abshar Abdalla. Di wadah inilah ide-ide gila mereka dikeluarkan secara lebih intens.

Ciri gagasan gila mereka adalah berisi gugatan terhadap syariat Allah yang menurut mereka tidak sesuai dengan nilai-nilai kemanusiaan dan akal mereka. Hampir semua sendi agama ini telah digugat mereka seperti syariat tentang jilbab hukum had qishash jenggot jihad larangan perkawinan antar agama hukum waris makna syahadat kebenaran Al Qur'an dan yang paling tinggi adalah gugat an terhadap Islam sebagai satusatu agama yang benar.

Inti mereka tidak setuju dengan aturan-aturan Allah itu dan kemudian memunculkan gagasan yang berlawanan dengannya.

Seperti gagasan bahwa semua agama selain Islam adalah benar telah lama dilontarkan oleh mereka. Di antara oleh orang yang mereka anggap sebagai pelopor gerakan "Pembaharu Pemikiran Islam" di Indonesia Ahmad Wahib. Anak muda yang tidak diketahui di mana belajar agama ini berkata: "Aku bukan nasionalis bukan Katolik bukan sosialis. Aku bukan Budha bukan Protestan bukan westernis. Aku bukan komunis. Aku bukan humanis. Aku adalah semuanya. Mudah-mudahan inilah yang disebut muslim. Aku ingin orang memandang dan menilaiku sebagai suatu kemutlakan tanpa

\footnotetext{
9 John Rawls, A Theory of Justice, London: Oxford University press, 1973, yang sudah diterjemahkan dalam bahasa indonesia oleh Uzair Fauzan dan Heru Prasetyo, Teori Keadilan, Yogyakarta: Pustaka Pelajar, 2006
} 
menghubung-hubungkan dari kelompok mana aku termasuk serta dari aliran mana saya berangkat."

Ahmad Wahib yang keseharian sering bergaul dengan para romo Katolik dan mendapat banyak 'kebaikan' dari mereka berkata tentang teman dekat itu: “Aku tidak yakin apakah Tuhan tega memasukkan romoku itu ke neraka."

Dengan berbagai pernyataan yang nyleneh itu dalam usia yang masih muda Ahmad Wahib telah menjadi "tokoh" nasional kebanggaan salibis. Pujian setinggi langit untuk Ahmad Wahib banyak menghiasai media massa salibis semasa hidup .

Seruan yang sama juga sering dilontarkan Nurcholis Madjid dengan slogan pluralismenya. Inti sama yakni menyerukan bahwa semua agama memiliki kebenaran yang sama.Tokoh lain yang cepat "naik daun" krn lebih berani dalam mengeluarkan pernyataan-pernyataan adalah Ulil Abshar Abdalla. Tentang kebenaran agama selain Islam Ulil Abshar mengatakan: "Semua agama sama semua menuju jalan kebenaran. Jadi bukan Islam yang paling benar.”Dalam buku Fikih Lintas Agama hal. 214 disebuntukan: Ayat yang lebih tegas tentang keselamatan agama-agama lain adalah Surat Al-Baqarah ayat $62^{10}$.

Dalam buku yang sama hal. 20 disebuntukan: Kesamaan dan kesatuan semua agama para nabi juga ditegaskan oleh Nabi sambil digambarkan bahwa para nabi itu satu saudara lain ibu namun agama mereka satu dan sama. Salah satu adalah hadits AlBukhari Rasulullah Shallallahu 'alaihi wa sallam bersabda: "Aku lebih berhak atas 'Isa putra Maryam di dunia dan di akhirat para nabi adalah satu ayah dari ibu yang berbedabeda dan agama mereka adalah satu."

Pada hal. 21 disebuntukan: ...penjelasan tersebut menegaskan prinsip-prinsip hubungan antar agama yang dapat diturunkan dari Al Qur'an yang menegaskan ada pluralisme agama.

Kutipan-kutipan di atas memuat kesimpulan berikut ini:

- Bukan Islam yang paling benar.

-Agama-agama selain Islam adalah agama yang selamat.

-Pluralisme agama dibenarkan Al Qur'an dan hadits Nabi. ${ }^{11}$

\footnotetext{
${ }^{10}$ A. Susanto, Filsafat IImu, (Jakarta: Bumi Aksara, 2011), hlm 19

${ }^{11}$ A. Musthofa, Filsafat Islam, (Bandung, Pustaka Setia, 1997), hlm. 11
} 


\section{BANTAHAN}

Mereka berkesimpulan bahwa bukan Islam yang paling benar. Yang lain apapun agama itu -demikian yang tampak dari ucapannya- juga benar. Bahkan mungkin lebih benar dari Islam. Demikian yang dipahami dari ucapan mereka.

Allah Subhanahu wa Ta'ala berfirman:

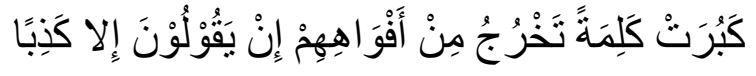

Artinya: "Sungguh besar kalimat yang keluar dari mulut mereka mereka tidak mengatakan kecuali dusta."

Sesungguh seorang muslim yang masih suci fitrah tahu kebatilan ucapan ini. Kalimat ini adalah ucapan kufur dan merupakan perkataan tentang agama Allah tanpa ilmu. Namun jika hati tertutup siapapun dia tidak akan mengetahui kebatilan bahkan lebih parah krn hal itu dianggap sebagai sesuatu yang benar. Alasan sepele: "Semua agama sama semua menuju jalan kebenaran.” Dengan mudah ia menyimpulkan dengan akalnya. Apakah tiap orang yang menuju kepada kebenaran itu akan sampai? Tentu jawab tidak. Ibnu Mas'ud mengatakan: "Betapa banyak orang yang menginginkan kebaikan tapi tidak mendapatkannya."12

Ini adalah sesuatu yang sama-sama kita saksikan. Tidak akan memungkiri kecuali orang yang congkak. Kalau jalan Yahudi Nashrani Majusi dan agama lain itu benar untuk apa Nabi mengajak mereka masuk Islam dan ketika mereka menolak terjadi permusuhan dan pertumpahan darah? Bagaimana kemudian dianggap agama selain Islam lebih benar?! Fa'tabiru ya Ulil Abshar!.

Kesimpulan kedua agama lain selain Islam adalah agama yang selamat arti tidak dimurkai Allah dan tidak diadzab.Tentu ini bukan ucapan seorang muslim dan tidak ada seorang muslim yang hakiki kecuali tahu betapa batil sesat dan kufur kalimat ini. Sayang ia mengelabuhi orang dengan berdalil surat Al-Baqarah ayat 62:

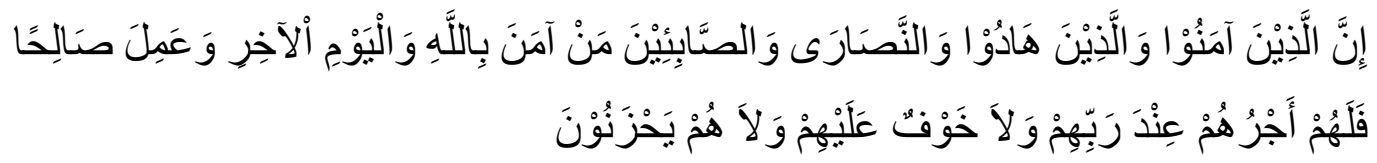

\footnotetext{
${ }^{12}$ Saebani, Beni, Filsafat Hukum Islam, Bandung: Pustaka Setia, 2007 hal.57.
} 
Artinya: "Sesungguh orang-orang mukmin orang-orang Yahudi orang-orang Nashrani dan orang-orang Shabi'in siapa saja di antara mereka yang benar-benar beriman kepada Allah hari kemudian dan beramal shalih mereka akan menerima pahala dari Tuhan mereka. Tidak ada kekhawatiran pada mereka dan tidak pula mereka bersedih hati."

Ia memahami ayat tersebut dengan akal yang sudah terkotori oleh noda pluralisme sehingga menganggap masing-masing dari Yahudi dan Nashrani benar dan selamat. Ibarat mereka seperti orang yang membaca ayat yang arti "Celaka orang yang shalat..." lalu berhenti dan tidak diteruskan. Atau ayat "Jangan kalian mendekati shalat..." dan tidak dibaca kelanjutan ayat "dalam keadaan kalian mabuk." 13

Sungguh ini adalah akhlak Yahudi yang beriman dengan sebagian ayat dan kafir dengan sebagian yang lain.

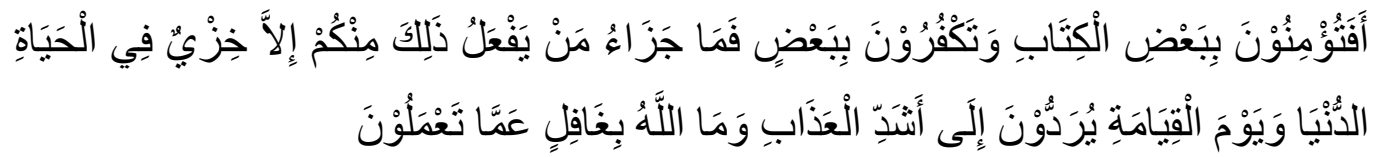

Artinya: "Apakah kamu beriman kepada sebagian Al Kitab dan ingkar terhadap sebagian yang lain? Tiada balasan bagi orang yang berbuat demikian daripadamu melainkan kenistaan dalam kehidupan dunia. Dan pada hari kiamat mereka dikembalikan kepada siksa yang sangat berat. Allah tidak lengah dari apa yang kamu perbuat."

Bukankah kita dalam memahami ayat Al Qur'an harus merujuk kepada ayat lain yang menjelaskan demikian pula merujuk kepada hadits Nabi yang Allah pasrahi untuk menjelaskan Al Qur'an? Dikemanakan firman Allah Subhanahu wa Ta'ala:

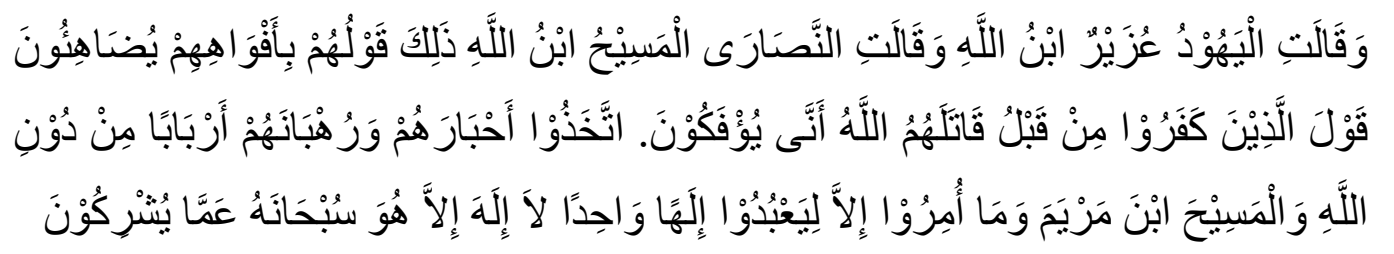

Artinya: “orang-orang Yahudi berkata: 'Uzair itu putera Allah' dan orang Nashrani berkata: 'Al Masih itu putera Allah'. Demikian itulah ucapan mereka dengan mulut mereka mereka meniru perkataan orang-orang kafir yang

\footnotetext{
13 Joachim Friedrich, Filsafat Hukum Perspektif Historis, Bandung: Nuansa dan Nusamedia, 2004, hal 239.
} 
terdahulu. Dilaknati Allah-lah mereka; bagaimana mereka sampai berpaling? Mereka menjadikan orang-orang alim dan rahib-rahib mereka sebagai tuhan selain Allah dan Al Masih putera Maryam; padahal mereka hanya disuruh menyembah Tuhan Yang Maha Esa; tidak ada Tuhan selain Dia. Maha Suci Allah dari apa yang mereka persekutukan."

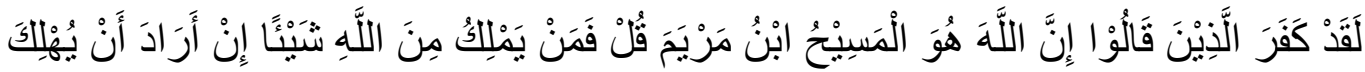

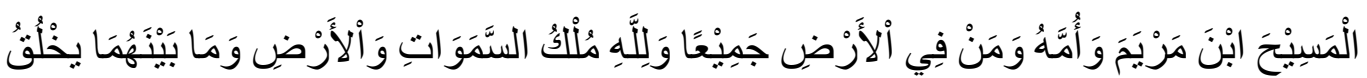

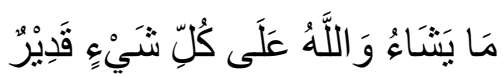

Artinya: "Sesungguh telah kafirlah orang-orang yang berkata: 'Sesungguh Allah itu ialah Al Masih putera Maryam'. Katakanlah: 'Maka siapakah yang dapat menghalang-halangi kehendak Allah jika Dia hendak membinasakan Al Masih putera Maryam itu beserta ibu dan seluruh orang-orang yang berada di bumi semuanya?' Kepunyaan Allah-lah kerajaan langit dan bumi dan apa yang di antara keduanya; Dia menciptakan apa yang dikehendaki-Nya. Dan Allah Maha Kuasa atas segala sesuatu."

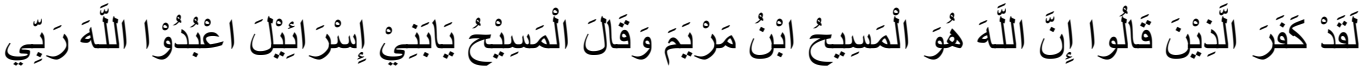

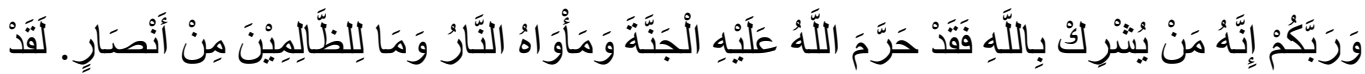

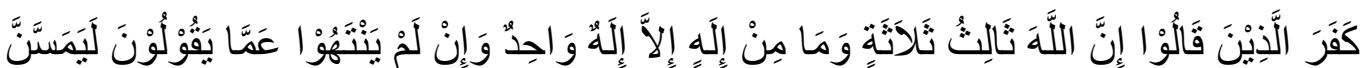

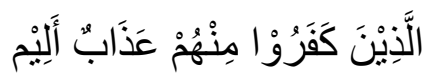

Artinya: "Sesungguh telah kafirlah orang-orang yang berkata: 'Sesungguh Allah adalah Al Masih putera Maryam’ padahal Al Masih berkata: 'Hai Bani Israil sembahlah Allah Tuhanku dan Tuhanmu'. Sesungguh orang yang mempersekutukan Allah mk pasti Allah mengharamkan kepada al-jannah dan tempat ialah an-naar tidaklah ada bagi orang-orang zalim itu seorang penolongpun. Sesungguh kafirlah orang-orang yang mengatakan: 'Bahwasa Allah salah satu dari yang tiga' padahal sekali-kali tidak ada Tuhan selain Tuhan Yang Esa. Jika mereka tidak berhenti dari apa yang mereka katakan itu pasti orang-orang yang kafir di antara mereka akan ditimpa siksaan yang pedih.” 
Dan sekian banyak ayat dan hadits lain yang dengan sangat tegas mengkafirkan mereka. Bagaimana mereka dikatakan selamat padahal Allah Subhanahu wa Ta'ala mengubah mereka menjadi babi dan kera:

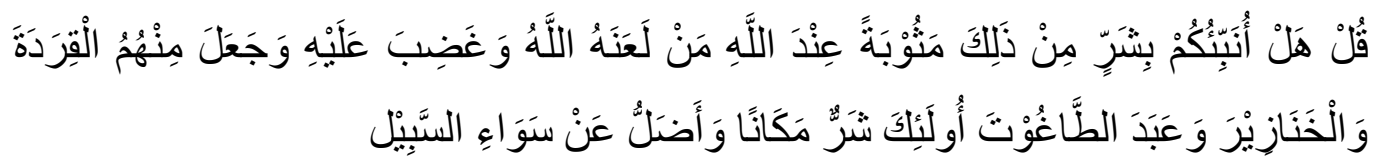

Artinya: "Katakanlah: "Apakah akan aku beritakan kepadamu tentang orangorang yang lebih buruk pembalasan dari itu di sisi Allah yaitu orang-orang yang dikutuki dan dimurkai Allah di antara mereka yang dijadikan kera dan babi dan menyembah thaghut?" Mereka itu lebih buruk tempat dan lebih tersesat dari jalan yang lurus.”

Allah Subhanahu wa Ta'ala melaknati mereka dengan lisan Dawud dan 'Isa:

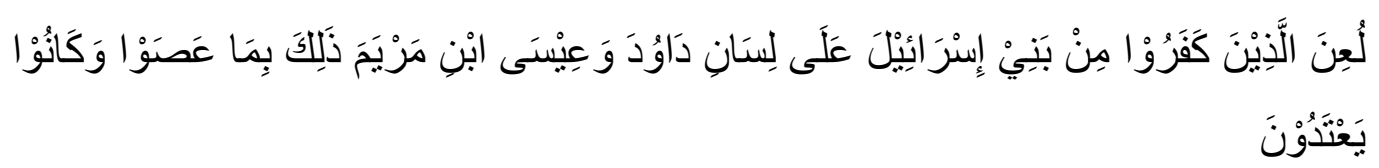

Artinya: "Telah dilaknati orang-orang kafir dari Bani Israil dengan lisan Daud dan 'Isa putera Maryam. Yang demikian itu disebabkan mereka durhaka dan selalu melampaui batas."

Nabi Shallallahu 'alaihi wa sallam bersabda :"Tidaklah mendengar aku seorang Yahudi atau Nashrani lalu tidak beriman dengan apa yang aku diutus dengan kecuali ia termasuk ahli neraka.” Kalau kita perhatikan baik-baik ayat yang dipakai sebagai dalil oleh mereka akan nampak bahwa ayat tersebut sama sekali tidak mendukung paham pluralisme dan maha suci Kalamullah untuk dikatakan mendukung pluralisme. ${ }^{14}$

Bukankah ayat tersebut memberikan syarat yaitu beriman kepada Allah? Apakah Yahudi dan Nashrani atau Majusi beriman kepada Allah? Jawab tidak! Karena beriman kepada Allah bukan hanya beriman dengan ada Allah. Bila hanya percaya dengan keberadaan Allah mk Iblispun beriman orang munafiq pun beriman dan Fir'aun pun beriman.

Tidak ada yang mengatakan demikian kecuali orang yang sejenis mereka. Iman kepada Allah mencakup keimanan tentang ada Allah dan keesaan yang tiada sekutu

\footnotetext{
${ }^{14}$ Muhammad Sa'id Ramdan al-Buti, Dawabit al-Maslahah fi as-Syariah al-Islamiyah, (Beirut: Mu'assasah ar-Risalah,1977), hlm.12.
} 
baginya. Sedangkan Yahudi menyekutukan Allah dengan 'Uzair dan Nashrani menyekutukan Allah dengan Nabi 'Isa 'alaihissalam.Di antara keimanan kepada Allah adalah meyakini uluhiyyah Allah yakni memberikan ibadah hanya kepada Allah dan meyakini hal itu. Sedangkan Yahudi dan Nashrani mereka beribadah kepada selain Allah bahkan kepada pendeta-pendeta.

Ayat itu juga memberikan syarat dalam beramal shalih. Yahudi dan Nashrani tidak melakukan amal shalih krn syarat amal shalih tidak mereka penuhi. Di antara yang merupakan syarat dasar yaitu iman tidak mereka penuhi. Kemudian ikhlas mereka juga tidak penuhi krn mereka beramal untuk selain Allah. Bagaimana mungkin mereka dikatakan selamat sementara tidak memenuhi syarat-syarat sebagai orang yang beriman. Pahamilah wahai yang berakal sehat. Jadi ayat ini berlaku bagi mereka yang memenuhi syarat-syarat tersebut. Dan ini berlaku sebelum datang Islam. Oleh karena Ibnu 'Abbas radhiallahu 'anhuma mengatakan bahwa setelah itu turunlah ayat 85 Surat Ali Imran:

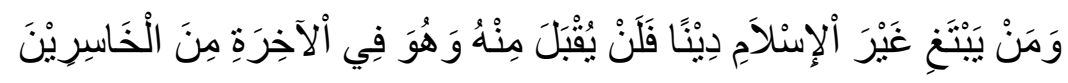

Artinya: "Barangsiapa mencari agama selain agama Islam mk sekali-kali tidaklah akan diterima dari dan dia di akhirat termasuk orang-orang yang rugi."

Di ayat lain Allah menganggap mereka bukan orang yang beriman kepada Allah dan hari akhir sebagaimana dalam ayat 29 Surat At-Taubah:

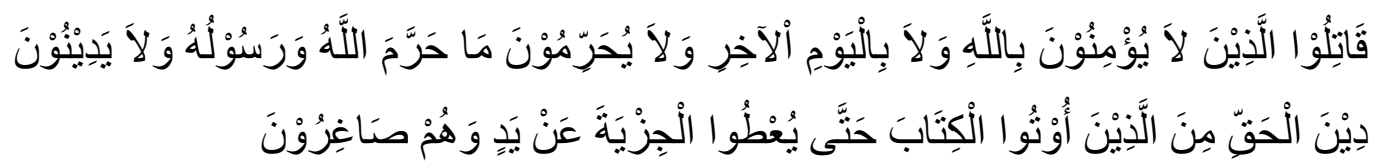

Artinya: "Perangilah orang-orang yang tidak beriman kepada Allah dan tidak kepada hari kemudian dan mereka tidak mengharamkan apa yang telah diharamkan oleh Allah dan Rasul-Nya dan tidak beragama dengan agama yang benar yang diberikan Al Kitab kepada mereka sampai mereka membayar jizyah dengan patuh sedang mereka dalam keadaan tunduk."

Adapun hadits yang mereka pakai juga tidak mendukung pluralisme sama sekali. Sebab kesamaan agama para rasul itu adalah pada inti yaitu agama tauhid dan beribadah hanya kepada Allah. Ternyata hal ini pun dilanggar oleh para pengikut rasul terutama setelah datang Nabi Muhammad Shallallahu 'alaihi wa sallam. Lantas bagaimana mereka bisa dianggap sama dengan ajaran Nabi Muhammad Shallallahu 'alaihi wa 
sallam? Hadits itu juga menunjukan bahwa syariat para rasul berbeda-beda. Itu yang dimaksud -wallahu a'lam-dengan saudara sebapak lain ibu?

Tapi pada praktek justru JIL ingin menyamakan syariat mereka semua sehingga membolehkan kawin dan waris beda agama. Tidak mungkin Nabi Shallallahu 'alaihi wa sallam yang berperang melawan Yahudi demi agama lalu menyabdakan sebuah hadits yang mendukung pluralisme agama. ${ }^{15}$

\section{DAFTAR PUSTAKA}

Al-Gazali, al-Mustasfa min Ilm al-Usul, Kairo: al-Amiriyah, 1412.

A. Susanto, Filsafat Ilmu, Jakarta: Bumi Aksara, 2011.

A. Musthofa, Filsafat Islam, Bandung, Pustaka Setia, 1997.

Beni Saebani, Filsafat Hukum Islam, Bandung: Pustaka Setia, 2007.

Carl Joachim Friedrich, Filsafat Hukum Perspektif Historis, Bandung: Nuansa dan Nusamedia, 2004.

Izzuddin ibn Abd al-Salam, Qawaid al-Ahkam fi Masalih al-Anam, Kairo: al-Istiqamat, t.t.

John Rawls, A Theory of Justice, London: Oxford University press, 1973, terj. Uzair Fauzan dan Heru Prasetyo, Teori Keadilan, Yogyakarta: Pustaka Pelajar, 2006

Masdar F. Mas'udi, "Meletakkan Kembali Maslahat Sebagai Acuan Syari'ah" Jurnal Ilmu dan Kebudayaan Ulumul Qur'an No.3, Vol. VI Th. 1995.

Muhammad Sa'id Ramdan al-Buti, Dawabit al-Maslahah fi as-Syariah al-Islamiyah, Beirut: Mu'assasah ar-Risalah, 1977.

Nur A. Fadhil Lubis, Hukum Islam dalam Kerangka Teori Fikih dan Tata Hukum Indonesia, Medan :Pustaka Widyasarana,1995.

Nur A. Fadhil Lubis, Hukum Islam dalam Kerangka Teori Fikih dan Tata Hukum Indonesia, Medan :Pustaka Widyasarana, 1995.

Theo Huijbers, Filsafat Hukum dalam lintasan sejarah, cet VIII, Yogyakarta: kanisius, 1995.

15 Carl Joachim Friedrich, Filsafat Hukum Perspektif Historis, Bandung: Nuansa dan Nusamedia, 2004, hal. 34. 